\title{
Skuamöz Hücreli Kanseri Taklit Eden Kutanöz Layșmanyazis Olgusu
}

\section{A Case of Cutaneous Leishmaniasis Mimicking Squamous Cell Carcinoma}

\section{Ali Murat Ceyhan, Gonca Meriç, Giray Aynalı*}

Süleyman Demirel Üniversitesi Tıp Fakültesi, Deri ve Zührevi Hastalıklar Anabilim Dalı ve

*Kulak Burun Boğaz Hastalıkları Anabilim Dalı, Isparta, Türkiye

Özet

Kutanöz layșmanyazis (KL) infekte tatarcıkların deriyi ısırma esnasında bulaștırdığı Leishmania genusuna ait protozonların neden olduğu paraziter bir hastalıktır. Dünyanın pek çok yerinde ve ülkemizde halen önemli bir sağlık sorunudur. Sıklıkla çocukluk yaș grubunda görülmektedir ve lezyonlar daha çok yüz, boyun ve ekstremiteler gibi vücudun açıkta kalan kısımlarında yerleșim göstermektedir. Endemik bölgelerde ve tipik özellikler gösteren vakalarda tanı koymak oldukça kolaydır. Fakat hastalığın deri belirtileri oldukça çeșitlilik gösterebilmekte ve sık görülen birçok dermatozu taklit edebilmektedir. Leishmania alt tipi, konağın immün yanıtı ve yașına bağlı olarak hastalık oldukça farklı ve atipik bulgular ile seyredebilmekte ve ilk muayenede KL tanısı kolaylıkla atlanabilmektedir. Kutanöz lezyonlardaki bu çeșitlilik ve sıra dıșı bulgular, özellikle KL'nin nadir görüldüğü non-endemik bölgelerde deneyimsiz hekimler açısından tanısal zorluğa neden olabilmektedir. Bu yazımızda non-endemik bölgede yașayan ve çiftçilik ile uğrașan 76 yașındaki kadında skuamöz hücreli kanseri taklit eden bir KL olgusunu sunuyoruz. (Türkderm 2012; 46: 44-6) Anahtar Kelimeler: Kutanöz layșmanyazis, ayırıcı tanı, skuamöz hücreli kanser

\section{Summary}

Cutaneous leishmaniasis (CL) is a parasitic disease caused by protozoan belongs to the Leishmania genus and is transmitted to human skin by the bite of infected sand flies. It is still considered an important health issue in many parts of the world including our country. $\mathrm{CL}$ is most commonly seen in childhood and the lesions more frequently occur on the exposed parts of the body such as the face, neck and the extremities. The diagnosis of $\mathrm{CL}$ is quite easy in typical cases found in the endemic areas. However, the clinical spectrum of $\mathrm{CL}$ can be very broad and it can mimic a number of common dermatoses. Depending on subspecies of the Leishmania, immune response of the host and age, it may represent quite different and atypical cutaneous manifestations which elude diagnosis in the first instance. The variety of cutaneous findings and unusual presentations can lead to diagnostic challenge especially for inexperienced physicians in non-endemic areas where the disease is less frequently seen. In this report, we describe a case of CL which clinically mimicked squamous cell carcinoma in a 76-year-old female farmer living in a non-endemic area. (Turkderm 2012; 46: 44-6)

Key Words: Cutaneous leishmaniasis, differential diagnosis, squamous cell carcinoma

\section{Giriş}

Kutanöz layşmanyazis $(\mathrm{KL})$ infekte flebotomların deriden kan emme işlemi esnasında bulaştırdıkları Leishmania protozonlarının neden olduğu, deride kötü görünümde elek tarzında skar ve şekil bozuklukları ile seyreden paraziter bir hastalıktır. Ülkemizde endemik olarak görüldüğü bölgeler dışında büyük metropolleri tehdit etmeye başladığı ve non- endemik bölgelerde de görülme sıklığında belirgin bir artış olduğu dikkati çekmektedir1-3. Son yıllarda, tipik klinik bulgular ile seyreden KL'in yanı sıra konağın immün cevabı ve Leishmania alt tipine göre değişiklik gösterebilen çok farklı klinik tipler rapor edilmiştir. Kutanöz morfolojideki çeşitlilikten dolayı, KL sık görülen pek çok dermatozu taklit edebilmekte ve endemik olmayan bölgelerde tanı ve tedavide yanılgılara yol açabilmektedir3-6. 


\section{Olgu}

Yetmiş altı yaşında kadın hasta, sol yanakta yara yakınması ile polikliniğimize başvurdu. Hastanın bu yakınmalarının ilk olarak yaklaşık 6 ay önce deriden hafif kabarık sivilce benzeri küçük bir kızarıklık şeklinde başladığı ve zaman içerisinde giderek etrafa doğru genişlediği öğrenildi. Ağrı, kaşıntı, yanma gibi herhangi bir subjektif yakınma tariflemeyen hastanın yüz bölgesine travma ve böcek ısırığı öyküsü yok idi. Açık ten rengi ve renkli göz yapısına sahip olan hasta çiftçilik ile uğraşmaktaydı ve uzun süre güneş maruziyeti öyküsü mevcuttu. Dermatolojik muayenede burun kanadı ve yanaklarda hiperpigmente maküller ve sol maksiller bölgede $1 \times 2 \mathrm{~cm}$ boyutunda üst yarısı sıkıca yapışık sarımsı kurut ile kaplı vejetasyon gösteren nodüloülseratif lezyon saptandı (Resim 1).

Burdur'un Tefenni ilçesinde ikamet eden ve $K L$ açısından endemik bölgelere seyahat öyküsü olmayan hastanın nodüloülseratif lezyonundan alınan dermal kazıntı örneğinin Giemsa boyası ile incelenmesi sonucunda leishmania cisimcikleri olarak da adlandırılan hücre içi (Resim 2) ve hücre dışı yerleşimli çok sayıda amastigot yapısında parazitler izlendi. Klinik ve Tzanck yayması bulguları ile hastaya KL tanısı konuldu. Bir hafta ara ile lezyonun tamamını beyazlatacak miktarlarda (ortalama $2 \mathrm{ml} /$ seans) intralezyonel sodyum stiboglukonat (Pentostam ${ }^{\circledR}$ ) ve injeksiyondan 5-10 dakika önce lezyon sınırından itibaren $2 \mathrm{~mm}$ 'lik sağlam deri alanını da içine alan 10-15 sn'lik çift donma erime döngüsü şeklinde kriyoterapi (3 hafta süre ile) uygulandı. Yedinci kür intralezyonel tedavi sonrasında noduloülseratif lezyon tamamen geriledi (Resim 3).

\section{Tartışma}

$\mathrm{KL}$, Leishmania genusundan bazı parazitlerin neden olduğu, ülkemiz de dahil olmak üzere yaklaşık 88 ülkede endemik olarak görülen bir hastalıktır. Güneydoğu Anadolu Bölgesinde özellikle Şanlıurfa ilinde hiperendemik, Çukurova bölgesinde ise endemik bir hastalık olarak yıllardır hüküm sürmekte ve halen önemli bir sağlık sorunu olmaya devam etmektedir2,3. Yalnız kırsal bölgeleri değil son yıllarda büyük metropolleri ve endemik olmayan bölgeleri de etkiler hale gelen hastalık milyonlarca kişiyi risk altına sokarak hem kişisel hem de sosyal pek çok olumsuzluklara neden olmaktadır³.

KL sıklıkla çocukluk yaş grubunda görülmektedir. Hastalık yaz aylarında tatarcıklar tarafından ısırılan kişilerde 2-8 aylık inkübasyon döneminden sonra genellikle vücudun açıkta kalan kısımlarında yerleşim gösteren asemptomatik, eritematöz papül şeklinde başlar. Lezyonlar ortalama 4-6 ay içerisinde 1-2 cm'ye ulaşıp ülserleşir ve zamanla bu ülserin üzeri tabana sıkıca yapışık krutla kaplanır. Tedavisiz bırakıldığında ise ortalama 1 yıl içerisinde elek şeklinde skar bırakarak iyileşir2,3. KL, sık görülen papüloülseratif tipinin yanı sıra çok farklı klinik şekillerde ortaya çıkabilmekte ve birçok dermatolojik hastalığı taklit ederek özellikle non-endemik bölgelerde tanı ve tedavide gecikmelere ve gereksiz tedavilere yol açabilmektedir ${ }^{3-6}$.

Kutanöz bulgulardaki morfolojik çeşitlilikten dolayı endemik bölgelerde bazı yazarlarca KL, sifiliz gibi "büyük taklitçi" olarak kabul edilmektedir. Klinik olarak KL lezyonları fronkül, karbonkül, ektima, erizipel, selülit ve impetigo gibi bakteriyel hastalıklar ile sıkça karıştırılabilmektedir. Infekte böcek ısırığı, DLE, lupus vulgaris ve

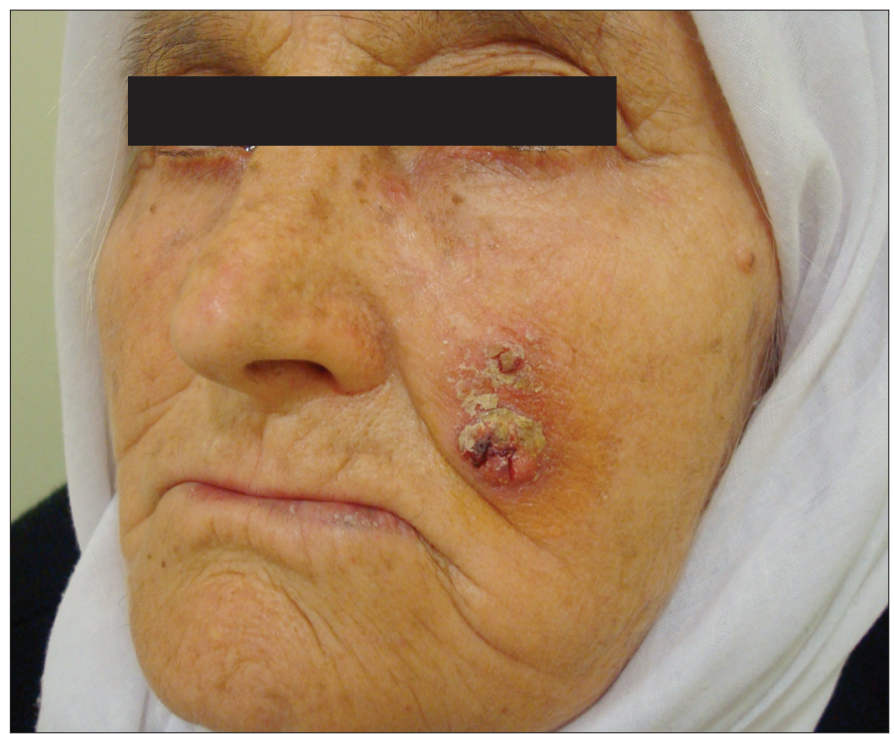

Resim 1. Sol maksiller bölgedeki vejetatif görünümlü kurutlu nodüloülseratif lezyon

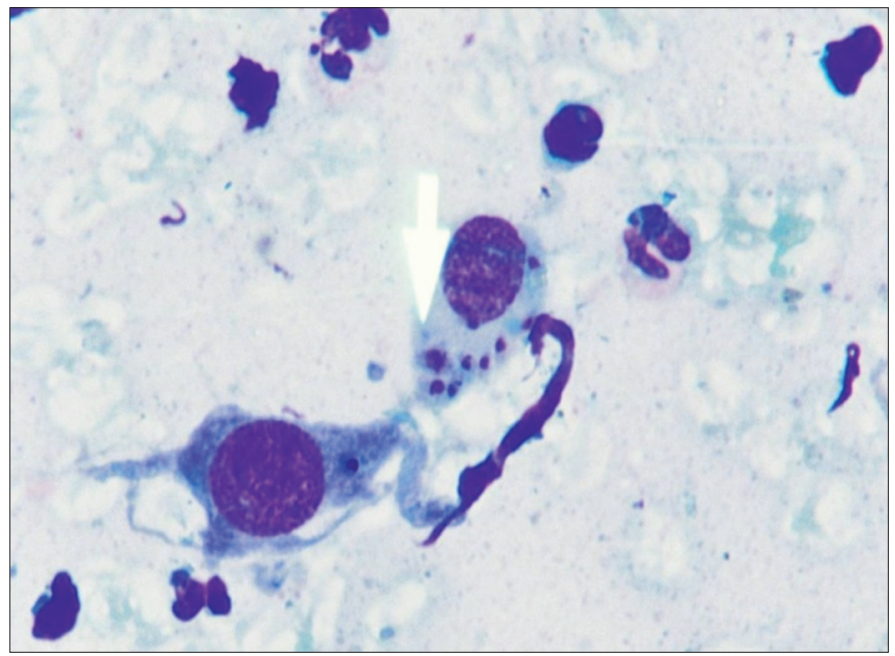

Resim 2. Intraselüler yerleşimli amastigotlar Giemsa X100

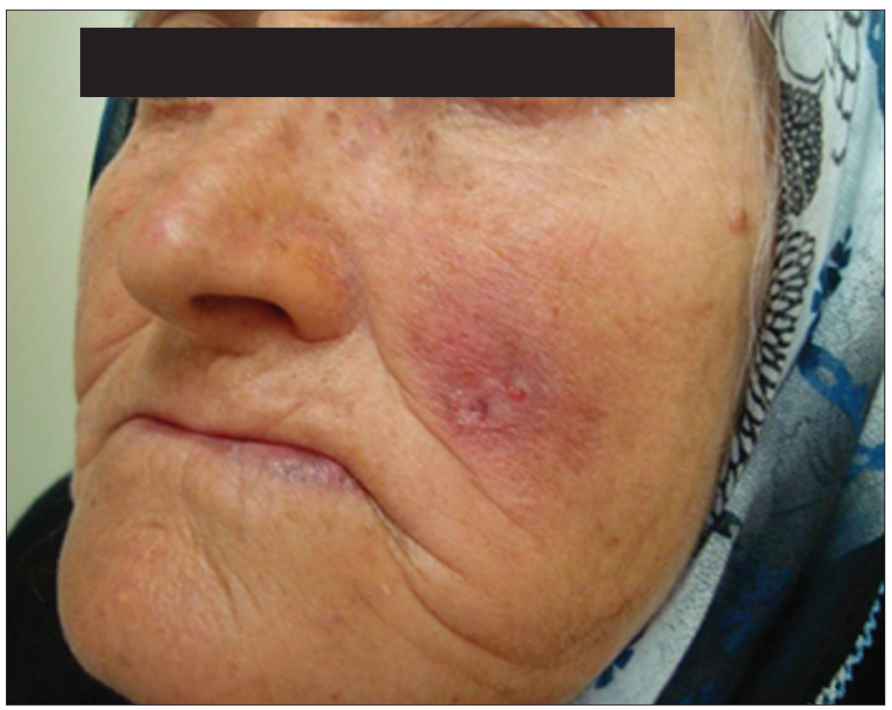

Resim 3. Yedinci kürden sonraki klinik görünüm 
derin mantar infeksiyonları ayırıcı tanıda düşünülmesi gereken diğer klinik tablolardır2-5.

Psoriaziform, paronişiyal, sporotrikoid, palmoplantar, zosteriform, annüler, ekzematoid ve verrüköz karakterdeki lezyonlar, KL'nin literatürde tanımlanan ve daha nadir görülen atipik varyantlarıdır3-5. Hastalığın kuluçka süresinin uzun olması, lezyonların uzun süre sebat etmesi, subjektif yakınmalara neden olmaması ve sıklıkla yüz bölgesinde yerleşim göstermesinden dolayı $\mathrm{KL}$, ileri yaşlarda ortaya çıktığında bazal hücreli karsinom (BHK) ve skuamöz hücreli karsinom (SHK) gibi deri malinitelerini de çok iyi taklit edebilmektedir3,6-8. Hastamızın; endemik bölgeye seyahat öyküsünün olmaması, ileri yaşta olması, mesleği ve bununla ilişkili uzun süreli güneşe maruziyet öyküsü, risk oluşturacak açık ten rengi ve renkli göz yapısına sahip olması ve lezyonun asemptomatik ve vejetatif karakterde olması ilk klinik muayenede mevcut lezyonun SHK olabileceği şüphesini uyandırmaktadır.

Bu tip lezyonlarda krutun ülsere bakan yüzeyinde kirli beyaz renkte dikensi çıkıntıların olması (çivi belirtisi) ve lezyon kenarının ortadaki ülsere doğru bir eğimle yükselmesi ile karakterize volkan belirtisi spesifik olmamakla ve her zaman eşlik etmemekle birlikte KL'yi akla getiren ve deri maliniteleri ve diğer kronik ülser nedenlerinden ayıran önemli bulgulardır. Hastanın ailesinde ya da bulunduğu coğrafik bölgede benzer yakınmaları olan kişilerin olması da KL şüphesini arttıran bir başka önemli bulgudur2,3. Bunun yanı sıra lezyonun alttaki dokulara sıkıca yapışık olması ve indürasyon göstermesi, komşu lenf bezi bölgelerinde ağrısız, fikse, sert ve büyük boyutlarda lenfadenopatilerin varlığı deri maliniteleri lehine olabilen bulgulardır. Olgumuzda lezyon alttaki dokulara fikse olmayıp hem çivi hem de volkan belirtisi negatif olarak değerlendirildi. Bulunduğu coğrafik bölgede ve aile yakınlarında benzer yakınmaları olan hasta öyküsü yok idi ve bölgesel lenfadenopati saptanmadı.

KL lezyonları sıklıkla kendiliğinden gerileme eğiliminde olsa da tedavisiz bırakılan olgular bulaş açısından kaynak ve risk oluşturduğundan dolayı ve kozmetik öneme sahip bölgelerde kötü görünümde deriden çökük skar oluşumunu önlemek için erken tanı ve tedavi büyük önem taşımaktadır. Bunun yanı sıra skar zemininde nadir de olsa BHK ve SHK gelişme riskinin olması da erken tanı ve tedavinin önemini arttırmaktadır2,3,6.

Ayırıcı tanı spektrumunun oldukça geniş olması nedeni ile klinik olarak $\mathrm{KL}$ tanısı konulmuş vakalarda tanı en az bir laboratuvar yöntemi ile doğrulanarak kesinleştirilmelidir. Bu amaçla en sık kullanılan ve en basit yöntem Giemsa ile boyanan dermal kazıntı yaymasında amastigot yapıda parazitlerin gösterilmesidir. Dermal kazıntı yaymasında parazitin gösterilemediği durumlarda ise histopatolojik inceleme, kültür ve PCR gibi daha ileri tetkiklere gereksinim duyulabilir2,3.

$\mathrm{KL}$ sağaltımında kriyoterapi, cerrahi eksizyon, karbondioksit lazer, elektrodesikasyon, küretaj, itrakonazol, ketokonazol, paromomisin vs. gibi birçok tedavi seçeneği yer alsa da günümüzde en etkili, en az nüks riskine sahip ve kozmetik olarak genellikle daha iyi sonuç alınan tedavi yöntemi beş değerli antimon bileşikleri ile antiinfektif tedavidir. Intralezyonel ve sistemik olarak uygulanabilir. Şiddetli mukoza tutulumunda, tedaviye dirençli rezidivan layşmanyazisde, multipl ve yaygın lezyonlarda sistemik tedavi intralezyonel tedaviye tercih edilir2,3,7. Olgumuzda sistemik antimon tedavisine gereksinim duyulmaksızın haftada bir kez intralezyonel tedavi uygulandı. Ayrıca lezyon içine zerk edilen ilacın bir kısmının başlangıçta ülsere alandan dışarı doğru sızıp etkinliği kısmen azalacağından dolayı intralezyonel tedavinin ilk 3 kürüne kriyoterapi de eklendi. Toplam 7 kür intralezyonel tedavi sonrasında tam iyileşme gözlendi.

Sonuç olarak son yıllarda non-endemik bölgelerde de görülme sıklığında belirgin artış olan KL, klasik tipinin yanı sıra çok farklı klinik şekillerde ortaya çıkabilmekte ve çoğu zaman tanısal zorluğa, yanlış ya da gereksiz tedavilere neden olabilmektedir. Bundan dolayı SHK benzeri lezyonlarda, KL non-endemik coğrafi bölgelerde de ayırıcı tanıda düşünülmeli ve klinik şüphe durumunda total eksizyon yapılmadan önce dermal kazıntı örneğinden yapılan Tzanck yaymasında Leishmania cisimcikleri aranarak tanı doğrulanmalıdır.

\section{Kaynaklar}

1. Baykal C, Ekinci AP. Türkiye'de kutane layşmanyazisin son durumu. Türkderm 2004;38:78-80.

2. Uzun S: Kutanöz leishmaniasis tanı ve tedavisi: Pratik yaklaşımlar. Dermatose 2002;4:32-8.

3. Uzun S: Leishmaniasis. Dermatoloji. Ed. Tüzün $Y$, Gürer MA, Serdaroğlu S, Oğuz O, Aksungur VL. 3. baskı İstanbul, Nobel Tıp Kitabevi, 2008;659-82.

4. Bari AU, Rahman SB: Many faces of cutaneous leishmaniasis. Indian J Dermatol Venereol Leprol 2008;74:23-7.

5. Ceyhan AM, Yıldırım M, Basak PY, Akkaya VB: Unusual multifocal cutaneous leishmaniasis in a diabetic patient. Eur J Dermatol 2009;19:514-5.

6. Akcalı C, Baba M, Inaloz S, Seckin D, Uzun S: Cutaneous leishmaniasis mimicking squamous cell carcinoma. Ann Acad Med Singapore 2008;37:435-6

7. Seyhan T, Durdu M, Borman H: Cutaneous leishmaniasis: a diagnostic challenge for plastic surgeons. Eur J Plast Surg 2009;32:87-93.

8. Khorsandi-Ashtiani MT, Hasibi M, Yazdani N, et al: Auricular leishmaniasis mimicking squamous cell carcinoma. J Laryngol Otol 2009;123:915-8. 